Swarthmore College

Works

Winter 2012

\title{
The Common Reader And The Archival Classroom: Disciplinary History For The Twenty-First Century
}

\author{
Rachel Sagner Buurma \\ Swarthmore College, rbuurma1@swarthmore.edu \\ L. Heffernan
}

Follow this and additional works at: https://works.swarthmore.edu/fac-english-lit

Part of the English Language and Literature Commons

Let us know how access to these works benefits you

\section{Recommended Citation}

Rachel Sagner Buurma and L. Heffernan. (2012). "The Common Reader And The Archival Classroom: Disciplinary History For The Twenty-First Century". New Literary History. Volume 43, Issue 18. 113-135. DOI: $10.1353 /$ nlh.2012.0005

https://works.swarthmore.edu/fac-english-lit/34

This work is brought to you for free by Swarthmore College Libraries' Works. It has been accepted for inclusion in English Literature Faculty Works by an authorized administrator of Works. For more information, please contact myworks@swarthmore.edu. 


\section{PROJECT MUSE}

\section{The Common Reader and the Archival Classroom: Disciplinary History for the Twenty-First Century}

Rachel Sagner Buurma, Laura Heffernan

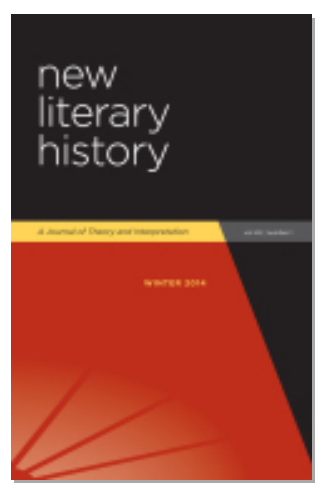

Published by The Johns Hopkins University Press

DOI: $10.1353 /$ nlh.2012.0005

$\Rightarrow$ For additional information about this article

http://muse.jhu.edu/journals/nlh/summary/v043/43.1.buurma.html 


\title{
The Common Reader and the Archival Classroom: Disciplinary History for the Twenty-First Century
}

\author{
Rachel Sagner Buurma and Laura Heffernan
}

\section{I}

N THE NEW MILLENNIUM A NEW figure beckons to the literary critic: the figure of the common reader. We see her out of the corner of our collective eye outside the classroom window or walking away from the back of the lecture hall; glimpsed in the public library stacks, but never in "the archive," she leaves her traces in blog comments and Amazon reviews. Her authority derives from her lack of credentials; neither scholar nor critic, student nor expert, she is defined largely by her undisciplinary and undisciplined reading practices. At times, she appears in her historical guise as a nineteenth-century reader of novels and newspapers, happily situated before the rise of English and its professional modes of interpretation. More often, she is called forth from these historical origins to remind contemporary literary critics that alternate engagements with literature lie just outside, or perhaps dormant within, our discipline.

And how does this common reader read? In Nicholas Dames's account, her reading is "tied to the rhythms of the body"; rapt or diffuse attention and discontinuous comprehension, rather than transcendental or final interpretation, are the essence of her reading practice. ${ }^{1}$ In David Kurnick's telling, she is a novel reader who cares little about closure or formal structures, preferring to immerse herself in the "details and complications" to be found in novels' "middles."2 In other accounts she reads more referentially than her professional counterparts; instead of seeking the organic unity of the work, she is attentive, according to Mary Poovey, to how the work "use[s] language in a referential manner to invoke the world outside its pages." For Elaine Freedgood, the Victorian novel reader is singular in her awareness of the metonymies that link the commodities in novels to the worldly contexts of their productions. ${ }^{4}$ For John Guillory, the "lay reader" abandons the cleric's "ritual orientation to the text." Where the clerisy reads intensively-slowly and repetitively with the goal of verbatim memorization-the lay reader of novels and newspapers reads "extensively." For Rita Felski, lay readers 
value experiences of recognition, enchantment, shock, and knowledge ("modes of engagement" that, Felski argues, scholarly readers share but often disavow). ${ }^{6}$

As these descriptions suggest, the common reader emerges not as a member of a sociological demographic but rather as a mascot, muse, or model for critics who have become impatient with what they see as the routinized protocols of professional reading in English. In this sense, we can see shades of the common reader in Sharon Marcus and Steven Best's "surface reading," a style of reading that strategically adopts a naive stance in its dedication to "literal readings that take texts at face value," or in Franco Moretti's chastening of hermeneutic modes of professional reading via his own model of "distant reading" (and even, perhaps, in his own charmingly casual writing style). ${ }^{7}$ The common reader, presiding over nearly all methodologically minded interventions of recent years, seems to offer license to us professionals to abandon our training, take a page out of her book, and then read it: referentially, nonsuspiciously, with affect, and only until we become distracted or bored.

Such a widespread celebration of deprofessionalized reading practices should lead us to ask: how have we become so down on our professional practices? Or, perhaps more to the point, how have our reading practices come to seem merely professional-meaningful only in relation to our institutional positions and professional desires? Someone taking stock of recent work on methodology might feel that ideology critique and aesthetic formalism are the only two interpretive modes that scholars have to offer, and further that such interpretive practices are gestures solely designed to give life to the profession. Thus Marjorie Levinson's assessment of recent "new formalist" work sees such interventions as more concerned with "prestige" than "praxis"; Jim English sees theories of literary form as attempts to "create and consolidate an institutional place for literary study." Ideology critique, too, has come to seem more self-serving than broadly interventionist: Sharon Marcus and Stephen Best argue that Fredric Jameson's symptomatic reading practices achieved prominence because they "presented professional literary criticism as a strenuous and heroic endeavor, one more akin to activism and labor than to leisure, and therefore fully deserving of remuneration." 9 This hardened connection between institutions and interpretive practices is usually regarded as a problem, but it sometimes appears as a wish, as when Jane Gallop argues that "close reading" is "the most valuable thing English ever had to offer ... the very thing that made us a discipline, that transformed us from cultured gentlemen into a profession." ${ }^{10}$

Such disciplinary autocritiques are voiced from a strange, somewhat faraway place. The vantage point they occupy is outside the discipline-it 
is, quite often, the vantage point of the sociologist who sees the pedagogical and scholarly practices of English as symptoms of something far more concrete: the social facts of institutions and their competition in wider fields for various kinds of capital. (Indeed, if we are in the position of the sociologist, that sociologist is probably Pierre Bourdieu, for whom intellectual arguments and practices should always be understood, at least in part, as struggles for legitimacy and recognition). The power of such sociologically savvy accounts of our discipline seems to grow in proportion to their lack of interest in the histories of the objects and theories of English.

In such a claustrophobic atmosphere, one in which the most authoritative accounts of our interpretive practices see them as meaningful only in relation to our own professional desires, the allure of the common reader becomes clear: her reading practices cannot be ascribed to any such institutional determinants. Positioned neither with the sociologist nor the literary critic, she proffers the possibility of reconnecting with the everyday life of literary engagement. Where our interpretive models seem to tell stories only about ourselves, she stands for the possibility that literature might be about something other than us. Accounts of her reading practices therefore emphasize their glorious referentiality: where our interpretations ensconce texts in ivory towers, hers connect texts to the world. Where disciplinary self-critique drains our interpretive practices of their value, her reading practices suggest that literary texts accrue value through their myriad connections with a world beyond the canon.

Perhaps most powerfully, the common reader reminds us that we are not only practitioners of a discipline, but people in the world. Bruno Latour, addressing the impasse of disciplinary critique, offers a similar reminder that inside each sophisticated skeptic lies a person with values and interests. While critique, Latour argues, simply debunks facts you don't believe in (literary interpretation, for instance) with appeals to those you do believe in (institutional prestige), you remain "a perfectly healthy sturdy realist for what you really cherish — and of course it might be criticism itself, but also painting, bird-watching, Shakespeare, baboons, proteins, and so on."11 Latour invites critics to bridge the divide between their interested, everyday selves and their debunking, professional selves in order to reimagine the critical urge as one that "adds" rather than subtracts "reality to matters of fact." substitutes a "reparative" reading practice for a "paranoid" reading practice; while the latter confirms its own knowing distance from the world, the former seeks, through addition and accretion, to "confer plenitude on an object that will then have resources to offer to an inchoate self." ${ }^{\prime 3}$ 
Latour and Sedgwick describe a new spirit of inquiry that does not proceed from or create such sharp divisions between facts and values, professional readers and common readers, things we create knowledge about and things we need or love. Indeed, considered this way, Latour and Sedgwick lead us to ask: why must we create a common reader at all-a figure who refigures oppositions that beg to be dismissed? Is it not one further sign that we have fallen out of love with our discipline? That we have failed to view our own everyday practices of teaching and research as resources with which to build new and exciting ways to value and study literature? ${ }^{14}$

In what follows, we perform a reparative disciplinary history. We propose to treat this history as a resource rather than an embarrassment, and we turn to the most unloved and understudied aspect of our discipline's history: the classroom. The classroom is admittedly a counterintuitive place to begin in order to deemphasize the opposition between professional and common readers. Indeed, we professors of literature think of the classroom as the place where our professional practice-literally, the difference we make-is performed for students and imprinted upon them. Here we are not interested, however, in these moments of disciplinary justification, transformation, or pure enjoyment. Instead, we look to the downtimes in the classroom hour, the tangents of discussion, the undertheorized moments of interpretation or historical conjecture, and the value bestowed simply by paying attention, finding in them a set of paths not so much not taken, as never mapped. Together, they form a new topography of the everyday life of our disciplinary practices; such practices might be revalued and theorized as we look forward to our discipline's future.

To begin to chart such a topography, we reconstruct the midcentury classrooms of Cleanth Brooks and Edmund Wilson through a study of previously unexamined archival materials stored in the Beinecke Library at Yale. From a disciplinary standpoint these two teachers seem quite opposed: Brooks a formalist, Wilson a historicist; Brooks a critic with a special relationship to disciplinarity, Wilson a critic with a special relationship to journalism and common readers. If the classroom, as a figure, often presides over such oppositions, the materials of Brooks's and Wilson's classrooms-their syllabi, course descriptions, lecture transcripts and notes, handouts, graded papers, and scholarly publications-call into question our habitual distinctions between literary critics and common readers, formalist teaching and historicist research.

Readers might imagine that they already know what Brooks's classroom looked like, for even to mention the New Critical classroom evokes familiar images: rows of desks filled with GI Bill students, mimeographed 
poems on a single page, a charismatic-democratic teacher intent upon clearing away all of the "specialized rubbish ... standing between the reader of a poem and the poem." ${ }^{15}$ Above all, the New Critical classroom is remembered, with loathing or longing, as the place where close reading provided literary critics with a powerful account of both their specialization and their wider appeal. And indeed, we found in Brooks's archive a story of how he built this strong theory that designated literature as a disciplinary object of study and a rarified aesthetic experience with public value, in part by figuring the classroom, in his published writing, as paradoxically both professional and public. Yet, in the temporal, participatory space of Brooks's actual classroom, this strong theory comes to seem a more fragile and uncertain thing. Alongside moments in Brooks's teaching when his close readings capture the distinctiveness and value of the literary appear other low-key, untheorized practices of discernment and evaluation. We examine the uneven methods of Brooks's seminar not to debunk New Critical formalism, but to explore the making of this theory as well as the ways that this strong theory-still held by many as equivalent to literary pedagogy then and now-fails to incorporate so many other kinds of attention, reading, historical imagination, and textuality at work in that same space.

One of Brooks's main contentions was that formalist pedagogy would provide an account of literary value that historicist scholars had failed to develop. However, turning to Wilson's classroom materials, we see how Wilson's historicist research provides its own aesthetic and mode of value-one that links texts to life experience rather than sanctifying them within a rarified canon, one that sees literary value accrue to texts as they are read and interpreted over time by varying readerships. Where Brooks operates from a center of literariness and canonicity that he himself builds, Wilson is most interested in the moments in which unliterary texts become literary (or vice versa), and the moments in which research takes its life from pedagogy as much as from publication. Ironically, with its more flexible sense of the location of literariness and its understanding of research as an investment of time and energy that conveys value upon its objects of study, Wilson's classroom lives Brooks's figure, connecting professional practices with public ones, research methodologies with evaluative judgments.

In bringing our own scholarly research to bear on the classroom (and in teaching this same material, for this article began life as jointly organized seminars at Swarthmore College and the University of Pennsylvania) we hope to model the ways that-as evidenced in Wilson's teaching-historicism creates value. Indeed, to imagine that it doesn't-that it produces only knowledge, that it creates facts rather than values-is to 
reproduce the logic that distinguishes between research and teaching, disciplinary spaces and public ones, skeptical critics and invested common readers. Exploring, like Wilson, a historicism that is critical and yet not only critical, in turn, allows us to evade the deadening impasse of disciplinary autocritique without reinstating a formalist vision of our practice that must ignore the ways that we connect students, publics, texts, and histories in our everyday professional lives. In so doing we hope to foster methodologies that are not yet literary, methodologies that will sustain us in the present by imagining possible futures for our discipline.

Mid-Century Classroom \#1: Cleanth Brooks at Yale University

To the members of English 300-K (Summer Session of 1942, University of Michigan) who discussed the problems with me and helped me work out some of the analyses

-Dedication to Cleanth Brooks's The Well Wrought Urn

In his published writing, Brooks figures the classroom as a space at once disciplinary and public, where the close reading of a poem helps the discipline make a sharp distinction between literary language (its stated object of study) and nonliterary language, while also helping students, who stand in a metonymic relation to a wider public, experience the rarified value of the literary. The classroom's productively paradoxical status is apparent in a text like "The Language of Paradox," the first chapter from The Well Wrought Urn. The essay is peopled by students who have "the greatest difficulty in accounting for" the "goodness" of poems; scholars for whom poems are significant only in terms of "'facts,' biological, sociological, and economic"; and the Brooks-narrator who performs a close reading of Donne's "The Canonization." Brooks's reading introduces a distinction between richly connotative poetic language and the denotative language of "the scientist ... purged of every trace of paradox." Brooks suggests that the scholars who research poems mistake themselves for scientists-blind to the metaphor of Donne's phoenix, they instead "test" its ashes "for their chemical content." ${ }^{16}$ These scholars read all poems referentially. Because they fail to recognize the literariness of poetic language, they cannot help their students develop what the students already sense intuitively on their own: the value or "goodness" of good poems. ${ }^{17}$

Meanwhile, the wider world's growing reverence for facts (of which quasi-scientific scholars of literature are a symptom) places poetry's value into relief: poetry alone can restore to the world all that rationalism 
has drained from it. In The Well Wrought Urn, poetry's value increases as it becomes more marginal within modern society; in a sense, poetry's confinement to the classroom actually confirms its value. Like the "pretty rooms" that Donne's speaker and his lover build in "The Canonization" to escape the world, only to discover they have "gained the world in each other, now a more intense, more meaningful world," the classroom protects poetry's rarified value and, in doing so, becomes worldly: "The unworldly . . become the most "worldly' of all" (as Brooks says of Donne's lovers). ${ }^{18}$

Given the many unifications (disciplinarity and publicness, marginality and worldliness) offered by Brooks's figuration of the classroom, what-we wondered-would be gathered within the space of his actual classrooms? Brooks's archive, housed at the Beinecke Rare Book and Manuscript Library at Yale University, includes reserve lists, syllabi, and gradebooks from courses Brooks offered at Yale from 1947 to 1975, including English 71: Modern Poetry; English 150 on Wordsworth and Coleridge; and English 160: Twentieth-Century Literature. At the heart of the "Classroom Materials" section of the Brooks collection are a set of transcriptions of Brooks's lectures from English 71: Modern Poetry. Brooks offered "Modern Poetry" in the spring of 1963, and the lectures were recorded in preparation for publication with Bantam Books. ${ }^{19}$ The transcriptions seem almost verbatim and include student questions and responses.

English 71-a year-long course-covered poems by Hardy, Housman, Hopkins, Yeats, Lowell, H. D., Fletcher, Lawrence, Masters, Lindsay, Robinson, Frost, Masefield, Brooke, Pound, Eliot, and Stevens in the first term, and poems by cummings, MacLeish, Moore, Bishop, Crane, Jeffers, Ransom, Bogan, Adams, and Graves in the second. Both terms featured selections from Robert Stallman's critical anthology Critiques and Essays in Criticism, 1920-1948, including essays by Hulme, Rickword, Spender, Eliot, Penn Warren, Wellek, and Wimsatt and Beardsley. The Yale Course Critique for 1963 (written for students by students) reports that Brooks's lectures are "centered around individual poems," and that a final exam tests students' understanding of the critical essays and ability to use them "in a close analytical consideration of particular poems." In addition, course reserve lists included more than forty volumes of secondary material, including critical studies such as Elizabeth Drew's T. S. Eliot: The Design of His Poetry, biographies, and collected letters.

Each class focused on several poems by the same author or selections from longer poems. Yet we found almost no examples of a close reading in the style of Brooks's reading of "The Canonization." Instead, the elements that are so tightly braided in Brooks's exemplary readings 
appear in Brooks's classroom as individual strands: the parsing of the "plain sense" of a poem; the determination of how its techniques give meaning; the evaluation of the poem; the broader account of poetry's increasingly marginal role in modernity and its inversely proportional value. To read the archive materials is to understand that pulling all of this together in a single close reading while remaining within "the hour" (as Brooks often mentions) would be quite an achievement. In practice, Brooks spent most classes focusing on smaller parts of poems and appreciating the author's technique, as he does when teaching Crane's The Bridge: "I think maybe the most useful thing that I can do, however, at this moment is to look at some particular passages with you, talk about them, the texture of them, the quality of them, and postpone a bit the matter of the total meaning of the poem and the way in which the parts are held together. As has just been remarked [by a student], the "Proem to Brooklyn Bridge" is really quite magnificent, and many of the figures that are used there come out quite splendidly." ${ }^{21}$ Throughout Brooks's lectures, we found this tension between a formalist reading that would account for the poem's "total meaning" through "the way in which the parts are held together" and a more local and evaluative "talk" about the "texture" and "quality" of particular passages that appreciates their splendor. On the one hand, English 71 occupied itself with deciding, with the aid of essays from the Stallman anthology, whether the poems studied were "poetry" or simply "prose." This formalist practice of separating the literary from the nonliterary was tempered, on the other hand, by a more evaluative approach that placed poems on a spectrum of aesthetic texture and value and even evaluated parts of poems against other parts. Brooks's classroom intersperses what Eve Sedgwick calls the "digital" (on/off) and the "analog" (multiply differentiated). ${ }^{22}$

As Brooks's comment above suggests, his classes were occupied with the "useful" work of getting a feel for particular poems and parts of poems. Brooks usually began by asking for a summation of the poem's dramatic context. He opens discussion on MacLeish's "Memorial Rain" by asking "What is the poem Memorial Rain about? What is the dramatic occasion? What is the city? Who's doing the listening? Who's doing the speaking?" ${ }^{23} \mathrm{He}$ would then read parts of poems line by line, making comments after each reading that either clarified vocabulary (the "nap" in Moore's "Jerboa" refers to "The nap of the fur" ${ }^{24}$ ) or drew attention to different elements of poetic technique, such as metaphor ("Why is the airplant called a bird, or almost a bird?" in Crane's "The Air Plant" imagery and mood ("we get this spacial [sic] image [in MacLeish's "You, Andrew Marvell"] of the shadow of night creeping on toward the west. . . This does much to build in a sense of the solemnity and magnificence 
but also sombre [sic] grandeur, the way in which empires go down under the impact of time"); grammatical structure ("How many 'ands' words occur in ["You, Andrew Marvell"]? Anyone count them?"26); or diction ("Why frightening?" Brooks asks about the phrase "frightening gills" from Bishop's "The Fish"- "I suppose because they seem so vulnerable that one can practically see the blood stream running there at the surface" ${ }^{27}$ ).

As Brooks notes the poems' plain sense and techniques, he also engages the language of appreciation. Particular techniques or images are "apt" or "brilliant," and individual poems are "admirable" or "magnificent" or "skillful." Brooks's close readings typically end with an evaluative summation. MacLeish's "You, Andrew Marvell" has "[a] great deal of depth of meaning." In Crane's "The Air Plant," "the imagination is working right straight through. The images are not dead decoration. They demand some kind of leap-answering leap—on the part of the reader." At times, poems are even valued for their statement rather than their technique. MacLeish's "Frescoes for Mr. Rockefeller's City" "is a very brilliant poem. It's a poem which I think actually in its political position is rather sane and fairly balanced." Brooks's evaluative statements seem to hover between an appreciation of the differences between these poems-differences that Brooks's students experience in the close attention afforded to each - and a universal standard of goodness.

At certain points, we can see the moment when close attention to a poem's particular textures and strengths is transformed into a judgment about its status as poetry or prose. Brooks wraps up a close reading of Moore's "England" with just such a reckoning: "This is a rather tart defense of one's homeland. The speaker is a little tired of people who throw off on America as being uncultured and incoherent and so on. On the other hand, though she's defending her country, she does it with a sense of humor, and she does it with some sense that she knows the rest of the world and can appreciate the rest of the world. The trouble is is it a poem? Well some of you will say, I suppose, that it is not a poem. It's a piece of prose, rather distinguished prose, but prose."

In such moments of decision, Brooks and his students draw upon Brooks's own theory of aesthetic formalism, supported and developed by the modernist and New Critical essays that Brooks assigned. In response to Brooks's assessment of Moore's "England," a student asks, "Earlier in the year you made remarks about the difference in poetry and a poem. Sometime would you come back to that again? I know that a poem goes beyond poetry." Brooks replies: "I would say that poetry as I used it then is the stuff of which poems are made. Precision, accuracy, a world rich in [sic] crisp-a world of the senses that's vivid, a world of exactness, a world of rhythm caught—all the sorts of things which we associate with 
the gift of the imagination and the arts of language. A poem, however, it seems to me, is more than just this sort of material thrown together in a sack or basket. It's articulated, it has its own form and arrangement." 28

Several classes before, Brooks elaborated this theory of a poem's "form and arrangement" in relation to MacLeish's "Ars Poetica," which contains the line "a poem should not mean but be." As Brooks explains, MacLeish finds his "analogies for poetry not in the usual terms of discourse but in terms of, oh, arts like painting, sculpture." Brooks elaborates: "Poems shouldn't be talky, they shouldn't be wordy. They should have a form which is so tight and condensed that one feels that instead of speaking out, the poem is speaking through the form." Brooks, noting that students should already be "familiar with that [idea] with some of the other poets and critics we've been talking about," mentions an essay by Stephen Spender, Penn Warren's "Pure and Impure Poetry," and Eliot's "Hamlet and His Problems," as well as Pope's idea that "a poem should do or be in itself what it is talking about." 99

Poems that fail to transcend the level of "prose" are just as important to the development of English 71's theoretical apparatus. Thus Moore's "Poetry" is of interest despite its failures: "Again, for those of you who say, 'I don't think this is a poem,' still, I think as a document it will be interesting and even exciting." ${ }^{30}$ Such interesting failures provide further occasions to delineate the difference between a poem's "form and arrangement" and prose's unrarified qualities: Moore's poem is "talky" and "wordy," it makes statements, and uses denotative language. (Indeed, Moore's "Poetry" itself raises the question of this distinction by pulling a quotation from Tolstoy's diary: "Nor is it valid / to discriminate against 'business documents and // school books': all these phenomena are important. One must make a distinction / however.") Yet Moore's poems fail, for Brooks, because they are excessively referential, containing footnotes citing the sources from which Moore draws quotations. Brooks downplays the importance of such citations: "I suppose it is a kind of amiable pedantry that makes Miss Moore put the quotes around them. Doesn't really matter. You don't have to know the reference."'11 Poems like Moore's seem to invite readers to imagine that their words, phrases, images, and quotations connect to real events-her footnotes evoke the moment when "in her reading in her Brooklyn apartment she picked that up, noted it down, stuck it away in a poem." For Brooks such references snake outward, endangering the poem's self-enclosed structure; their materiality threatens its universality, much as material source scholarship drains the profession of its account of literature's distinctiveness and its value..$^{32}$

Brooks works to make his classroom as self-contained as good poems should be and guards against a referentiality that would connect his 
classroom to the world in nonfigural ways. When references to historical events arise in poems in English 71, Brooks resolves them into symbolic situations. For instance, discussing "Memorial Rain," Brooks mentions that the poem is about MacLeish mourning his brother who died in World War I, only to deem this "personal point" irrelevant to the understanding of a poem that could be about any American. ${ }^{33}$ Brooks treats the recounting of background or the tracing of allusions as preliminary work that precedes the real work of close reading. On the Poe reference in Crane's "The Bridge," Brooks pauses: "Now, obviously, we've got a reference here, and let's see what the reference is, and then maybe we can make some effort to see what the poem is saying. What is the reference? Anybody know it?" 34 A discussion of MacLeish's "Frescoes" begins with a quick explanation of the poem's occasion that is largely drained of accurate detail and political import. ${ }^{35}$

When the world does enter into the classroom of English 71, it is an already figured world, given shape and meaning by themes and tensions. Brooks's lecture on MacLeish notes that MacLeish exhibits a "whole tendency apparently toward a highly individual and lyrical and private poetry. And yet this is a man whose career has been that of a public man, state department, Fortune magazine, Librarian of Congress, a man terribly interested in politics, very much interested in public affairs." MacLeish's poetry accordingly carries "this anxiety one almost feels inclined to say on the part of Macleish [sic], that poetry not become simply something both [crossed out] very [written in] private and remote from the concerns of the state." Brooks puts it to his students to decide whether MacLeish "really ever reconciled" these "twin tugs." ${ }^{\text {" If }}$ MacLeish's paradoxical position—both worldly and marginal—recalls the position of modern poetry itself (and the classroom as figured in The Well Wrought Urn), other poets seem simply marginal. Moore, for instance, is introduced as aligned with coteries and institutions of print: Brooks notes that she was involved with all of the "little movements and little special magazines," taught at the Carlisle Indian Industrial School in Pennsylvania, now lives in Brooklyn, had been recently awarded the Bollingen Prize, and was "a librarian for a while. ${ }^{\text {"37 }}$ Where Brooks presents MacLeish's life as ahistorical and synchronic-offering at all times an image of poetry's paradoxical position-Moore's life is a narrative. She changes, develops, and moves-indeed, the references in her poems seem to link the poems to particular moments along this temporal sequence.

Brooks's story of Moore's life points to a shadowy, alternate version of the classroom. This classroom is less figural and more real-it is the place where teaching and learning happen in time and the place that fills, "for a while," one stage in the course of a life. Brooks introduces this more temporal and historically located sense of the classroom at 
many moments in English 71: when he wishes to "stimulate, provoke" his students into "doing some more reading of MacLeish, thinking about him and finding out for yourself" whether he reconciled his "divergent interests," or when Brooks mentions a contemporary culture of letters that holds Bishop's work in "high esteem," even if Brooks himself does not. All of these moments acknowledge literary value as a changing thing - they point to how students' sense of literary value will change over the course of their education and life, and how the culture of letters' consensus about what is valuable changes too, as new members-perhaps even some of Brooks's students-join it.

This more temporal and historical sense of literary value-one that is analog where Brooks's strong theory is digital-is captured by Brooks's judgment that Moore's failed poem is nevertheless "interesting." Sianne Ngai, in her recent analysis of how "interesting" functions as an aesthetic judgment, explains this "link between the interesting and ongoingness." As Ngai points out, to declare an object "interesting" is to mark it-like "sticking a Post-It in a book"-in anticipation of returning to it later. In this sense, the aesthetic of the interesting "registers the simple fact (one strangely overlooked by much aesthetic philosophy) that time makes a difference in aesthetic evaluation." 38 Brooks's judgment that Moore's "Poetry" is "interesting" as a "document" seems likewise to point to a more contingent and temporal sense of literary value that exists alongside English 71's strong, theoretical elevation of formal poetry over "talky" prose. If Brooks's strong theory of literariness cannot account for the way he himself values Moore's poem, his classroom practices nevertheless remain open to the ways in which value accrues to texts by virtue of the attention that we pay to them in the temporality of our experience. This mode of value, like Moore's referential footnotes, snakes outward: it links to the ongoing nature of scholarly research, to experiences of aesthetic value that are low-key and long-lasting rather than instantaneous or transcendent, to a sense of multiple publics that cut across but are not contained by the classroom. Turning in the next section to Edmund Wilson's classrooms, we will see that Wilson offers an historicist method that builds upon and accounts for this alternate, changing, analog form of value.

Mid-Century Classroom \#2: Edmund Wilson at Smith, Chicago, and Harvard

To the Students of English 354

University of Chicago, Summer, 1939

-Dedication to Edmund Wilson's "Dickens:

The Two Scrooges" in

The Wound and the Bow 
Brooks's opposition between the self-contained poem and the referential "document" reappears in Wilson's teaching and research as a narrative in medias res. The poem (or, more often, the novel) is always on the verge of taking on the worldly functions of the document for Wilson, while a document in the correct company holds within it the literary potential of the poem. As Robert Martin Adams noticed in a 1948 Sewanee Review review, "The Triple Thinkers included observations that the functions of verse were being merged into those of prose, and that literature itself might in time be absorbed into the machinery of social planning. The tendency to think, and in fact to hope, that literature was about to become something else, was common to much of Edmund Wilson's early writing." ${ }^{9}$

Adams, sympathetic to Wilson's search for eddies of literary meaning within "the currents of history," nevertheless means this observation as a criticism; for him, Wilson's utopian fantasy of an order in which literature takes on referential functions is a dodge calculated to "delay or avoid the problem of literary value." ${ }^{40}$ Later critics similarly noticed "something peculiar about Mr. Wilson's taste in fiction ... he seems to want it to cease to be art and to turn into document, or at least assume the style of document." ${ }^{41}$ We argue, however, that Wilson's interest in the moment when literature becomes a document, or vice versa, was itself a methodology rather than a delay tactic or a peculiarity of taste. Wilson does not avoid the problem of literary value; rather, he studies and stages the moment when value shifts - the moment when literature becomes referential and touches or transforms the world, the moment when a document becomes literature, and our orientation towards it shifts as a new, provisional canon is formed. ${ }^{42}$ In a sense, Adams and others are correct that Wilson failed to theorize this methodology in print-most famously in "The Historical Interpretation of Literature" (1940) —yet his inherently historicist interest in how value shifts finds its true home, we argue, in Wilson's temporal, worldly classrooms rather than his printed texts. ${ }^{43}$ If we have failed to view the classroom as a site of methodological articulation, then, the failing is ours, and not Wilson's.

Wilson's interest in literature's tendency to "become something else" comes alive in the changing atmosphere of the teaching hour and the summer session. The duration of a single course allows Wilson to highlight the ways that literary value shifts through history, but also through a reader's individual returns to a single text. In a broad way, his courses transform the unliterary into the literary, as when he revalues the work of Dickens in a course at the University of Chicago during the summer of 1939, or when he teaches diaries, speeches, memoirs, and journalism as the "Literature of the Civil War" at Harvard in 1959-1960. Other 
courses, such as a class on Joyce at Smith College in 1942 or the "The Use of Language in Literature" at Harvard in 1958 explore the ways that literary texts like Finnegans Wake reference the world and thus become, for a moment, documentary. Just as Wilson connects the unliterary and the literary, so he treats his classrooms as sites where teaching and research connect. For Wilson, the classroom is not a testing ground for more finished published work; instead, it acts as a field upon which Wilson animates or reanimates his research process. Sometimes this link between teaching and research takes the form of a single topic that concurrently unfolds as both class and essay draft, as was the case during that summer of 1939, when Wilson taught a class on "Varieties of Nineteenth-Century Criticism" which supported his work on "The Historical Interpretation of Literature"; a sheet outlining the syllabus and first-day lecture for his criticism class turns over to reveal on the verso a set of penciled notes towards "The Historical Interpretation of Literature. ${ }^{{ }^{44}}$ At other times, the classroom provides the scene where a nearly finished book can be fully unfolded. Wilson's classroom is not a space within which research is translated in more or less sophisticated ways for a more or less receptive audience; it is rather the temporal, animating site where the referential world touches the literary text, where the building blocks of literariness are revealed to be everyday words, and where apparently autonomous and self-interested individuals yield themselves up as bundles of potentially researchable connections.

Wilson's pursuit of the connection between literariness and reference takes practical curricular shape in his assignment of theoretical texts and his in-class close reading exercises. The single theoretical text Wilson assigned to his class on Joyce was Stevenson's 1885 "On Style in Literature: Its Technical Elements." A primer focused on the sounds of consonants and vowels in poetry and prose, Stevenson's essay frames his close reading protocols by explaining that literature stands apart from the other arts, and much closer to the world, because "the material in which the literary artist works is the dialect of life." ${ }^{\prime 5}$ The basic elements of literature are "words, the acknowledged currency of our daily affairs," Stevenson notes, and so literature has both "a strange freshness and immediacy of address to the public mind," but is also by this same token limited because unlike the "plastic and ductile material" available to painters and sculptors, the writer "is condemned to work in mosaic with finite and quite rigid words." ${ }^{46}$ Analyzing the sounds patterns and structure in the poems of Coleridge and Shakespeare alongside the prose of Milton and Macaulay (in which he triumphs to find in one paragraph "a moment of FV in all this world of K's!"47), Stevenson's close reading traverses the literary and the everyday while assiduously avoiding any tight 
ties between sound and sense. The very nature of language therefore prepares the way for the possibility of the value transfer between poem and document at the core of Wilson's methodology.

In another class, Wilson's mimeographed handout (a classroom tool today overly associated with New Criticism) draws students' attention to the worldly, referential origin of a vast catalog of highly canonical literary texts. A handout titled "Sound of Bells" from "The Use of Language in Literature" excerpts fourteen different examples of bells represented in literature (including Mother Goose, Poe, Milton, Keats, James, Joyce, Eliot), while a handout titled "Objects Reflected in Water" excerpts Housman, Shelley, Auden, Yeats, Pope, and James Hogg and "Bird Song" includes bits of Nashe, Shelley, Aristophanes in Greek and two translations, Whitman, Arnold, Robert Bridges, Byron, Eliot, Tennyson, Virgil, Milton, and Turgenev ${ }^{48}$ Rather than the poem-on-the-page, Wilson offers his students long catalogs of parts of poems unified by single referents. $\mathrm{He}$ creates temporary genres- the bird song lyric, the reflection rhyme, the bell poem-that teach literary representation through a focus on literal reflection. This teaching technique sees a hospitable world organize a temporary but compelling canon (where Brooks might see the canon as an institutional force in the act of temporarily staving off the incursions of a chaotic and hostile world). And rather than imagining the close reading of literary texts as an inherently formalist exercise designed to confirm the literariness, and thus the value, of canonical texts, Wilson models a kind of close reading that identifies canonical literature's connection to the world-its everyday referentiality, its commonality with bird-watching guides and unspectacular shoreside sundowns and change-of-class bells-as itself a source of value.

While Wilson's handouts reconnect canonical literature to the world, many of his courses center on noncanonical texts that have been undervalued precisely because of their enmeshment with the everyday. For example, Wilson's Dickens class opens with a lecture that describes how literary culture has undervalued Dickens because of his popularity, a popularity that stems from his connectedness with winter holidays and before-bed reading and memories of school vacations. Wilson's notes, written in pencil on a yellow legal pad, read:

Everybody has read Dickens-enormously popular-Pickwick + Xmas Carol in England-symbol of Xmas, cheerful old England-English middle class. Not much criticism: Chesterton + Gissing-perhaps because everybody reads him early ++ the highbrows rather scorn him. Dickens was a great favorite of mine when I was a child-I've kept on reading him off + on all my life. Have come to have ideas about him which I'm going to try to explain in this course. I hope you'll criticize them + don't think that, in writing your papers, you have to accept my ideas-don't hesitate to contradict them. ${ }^{49}$ 
For the "highbrows," Dickens's enmeshment in everyday life is a mark against him; for Wilson, interested in studying the connections between Dickens's life, his novels, and his historical moment, it is generative. His course goes on to consider "Dickens' style," the ways that his novels related to his own "self-pity" ("I think: literature protected something"), and the ways that Dickens selectively represented the events of his moment (To represent the "Chartist agitation came to crisis in "40" in Barnaby Rudge, Dickens "chose [the] Gordon Riots.") Wilson's historicism considers the range of relationships that a novel can have to a life (and that a life can have to an historical moment); he creates value by creating interest around these connections, in a direct reversal of the logic of "highbrow" scorn. Whereas highbrows create value by building or invoking a canon, Wilson's more fluid historicist model of value acknowledges the contingency and historical specificity of literary value: a contingency and specificity that emerges in the ways that Wilson's own ideas about Dickens have changed—how he has "come to" them over a lifetime of reading - and in how his students are invited to arrive at their own conclusions and valuations.

Twenty years later, Wilson turns this historicist model to an apparently even less literary topic. His 1959-1960 "Literature of the Civil War" class at Harvard reanimates the research process of his nearly finished book, Patriotic Gore. Wilson begins his first day lecture by explaining that "I am going to give you the substance of a book I have been writing on the literature of the American Civil War. By the literature of the Civil War I don't mean simply any literature that deals with the Civil War. I confine myself to the writings of people who actually took part in the war or who had some direct connection with it." ${ }^{\circ 0}$ This choice of texts is framed by Wilson as in part an aesthetic one: "The poetry and the fiction and the drama inspired by the war itself are mostly extremely inferior," he notes, while "[t]he diaries, the letters, the memoirs, military, political and social, the speeches and official papers and the journalistic reports are the main literature of the Civil War" because they give us a sense of the fact that "there has never been an historical crisis in which the actors were more keenly aware of the roles they were playing before the world and in which they were more articulate." Under the pressure of a war carried out within a newly pervasive print culture, people come to see themselves as historical, and the documents of their self-conscious role-playing become therefore literary. ${ }^{51}$ Drawing this odd assortment of texts together in the act of teaching, Wilson uses history to hone in on the moments such records of everyday experience take on aesthetic form as they move through different institutional contexts. 
Yet Wilson's historicism resists turning history into the "spirit of the age" or any other coherent formation. Indeed, the terrain of his "Literature of the Civil War" is both messy and flexible. As he explains to his students, the course "begin[s] with Harriet Beecher Stowe, who did so much to arouse the North by the publication of Uncle Tom's Cabin, and ... end [s] —next spring — with Justice Holmes, whose whole view of the world and hence professional career were deeply influenced by his experience in the war. ${ }^{.52}$ Wilson steers clear of reifications, explaining that "My presentation of these figures will trace a consecutive development but it will not be strictly chronological. . . My argument[s] . . will all be presented in a series of literary portraits. I shall be dealing, to be sure, with tendencies, but mainly by implication. Societies and movements and wars are made up of individuals, and my story is all in terms of individuals. Of the career and personality of each I shall try to give a more or less well-rounded picture, so my lectures will be full of details that in a sense will not be relevant to my theses. ${ }^{.53}$

Wilson preserves a focus on the specificity of the individual not as a purely psychological subject, but as a bundle of potentially irrelevant but potentially connective details that make up "societies and movements," just as he presented Dickens and his novels as gatherings of possible connections. He rejects the idea of a deep historical truth organizing apparently autonomous individuals and texts. At the same time Wilson's goal is clearly not to offer a series of portraits that he values for their autonomous aesthetic value, or for the insights they give us into the individual authors they represent; his "well-rounded picture" of each "career and personality" is "full of details" not relevant to his thesis. Irrelevancies pose no threat to Wilson's thesis-indeed, we might say, following the logic of Wilson's own method, that irrelevancies are merely details that are not yet relevant. They await a future moment when some other critic will connect them in some new way, just as Wilson has gathered together this strange assemblage of "Literature of the Civil War."

Wilson's sense of individuals and texts as bundles of potential connections extends to the feel of his classrooms. Wilson's tendency to bring chance-met friends (like Saul Bellow) along to class, his references to everyday events ("Ford Maddox Ford died two days ago" ${ }^{54}$ ), the scribbled notes, copies of handouts, carefully preserved student papers, lecture plans, and hand-drawn charts of social relations (for teaching Marxist criticism) all offer evidence of his classroom's predisposition to act as a space that connects different kinds of people and unexpected texts. This principle even applies to the collection of students Wilson accumulates; a single Harvard class found graduate students in philosophy of language, English, and the school of education alongside undergraduate 
English, linguistics, history, and philosophy majors, a Radcliffe senior, an otherwise-unidentified student visiting from France, and a Radcliffe linguistics PhD candidate (and research assistant at Harvard Computation Laboratory on an automatic Russian translation project, "where I've been working on machine inflection" ${ }^{\prime 55}$ ). Whereas Brooks carefully figures current events for his entirely male Yale undergraduate audience, Wilson's classroom is designed to send tendrils outward to connect with the everyday lives of the figures-students from France, Russian-translating computers, chance visitors, and Civil War diarists-who crowd the often enrollment-capped classroom. While Brooks's classroom is a rarified space apart from the public sphere, Wilson's classroom cuts across multiple publics; in the case of his teaching of Joyce at Smith, Wilson combined a lecture open to the public with a supplementary two-hour seminar discussion to form a for-credit class. While Brooks works to produce a classroom that feels like a well-wrought urn, Wilson's classroom strives for the effect of a decent railway station bar.

Perhaps most importantly, Wilson's sense of the temporality of interpretation-specifically the sense that texts accrue value as they are read and reread both by individuals and groups-can only truly be modeled in the duration of the class hour and the semester course, coextensive with a life in which a reader returns to texts again and again, as Wilson has "kept on reading [Dickens] off + on all of my life." In Wilson's 1942 course on Joyce it becomes clear that the classroom fosters this temporal model of reading more readily than does the review or the essay. These lectures begin, "I have been reading James Joyce and writing about him ever since a Portrait of the Artist as a Young Man came out in 1916, ${ }^{, 56}$ indicating that only Wilson's living and speaking person can express the current state and ongoing project of his reading of Finnegans Wake (though his footnotes to the successive editions and collections of his writing on Joyce attempt to capture something of this ongoing project). As he explains in his opening lecture, he "Wrote reviews of Ulysses and Finnegans Wake" upon their initial publications but then he "Realized immediately [the] inadequacy of reviews. Such books can hardly be reviewed. As I reread the books, I saw that there was much more in them, both of meaning and of art, than I had understood at first. ${ }^{57}$

Joyce can't be reviewed because the mode of the review is a single act of analysis and evaluation; the punctual temporality of the review requires a model of the text as an autonomous object that can be known in a short, if intense, single evaluation and subsequently committed to paper and publication. As Wilson cautions the first-time reader in his review of "A Guide to Finnegans Wake," "A few . . . words of guidance. The conditions for reading this book are different, so far as I know, from 
those for reading any other ever written. You have to take it rather slowly, a section at a time, and you have to keep on rereading it. ${ }^{\prime 58}$ Rather than offer a representation of life all at once and upfront-as a Dickens novel might—-the slow, drawn-out lifelong rereading that Ulysses and Finnegans Wake require produces the sense of "a reality like life's," because the reader's slow building up of experience with the text, her accretion of detail and meaning over the successive years of her life, function to make the experience of reading the novel similar to the experience of living. That is, instead of imitating reality, the experience of reading Ulysses imitates the structure of the reader's encounter with everyday real life, the composition of a coherent and significant world out of a wealth of incoherent and disconnected detail and experience-an apt description of his pedagogy and of his classroom itself.

Indeed, it is perhaps because Wilson's criticism and his classrooms feel so much like everyday life-in which people take interest and make connections, thereby creating meaning and value-that they have never been described in a methodological register, as we have done here. Yet, in a contemporary moment in which literary critics are inventing a common reader figure to model these same kinds of reading practices- the ability to confer value by taking interest, the uneven apprehension of relevant and irrelevant details in literary texts, the sense that literature connects both to individual lives and the world-it is worth showing that such practices can be found within that most disciplinary of spaces, the midcentury classroom. Further, we argue, it is our own tendency to dismiss such practices as weak theories when we find them in disciplinary spaces-to let them go undescribed, just as we underdescribe elements of our own classroom practices-that secures false distinctions between professional and common readers. For in the downtime of the classroom and the duration of the semester, and even in the ungraded quiz and the half-finished handout, wait insights and details that are not irrelevant-only not yet relevant.

\section{Coda: Cultural Capital's Classroom}

We began this essay by suggesting that literary critics in the new millennium have internalized the sociological critique of their field. The origins of this Bourdieuvian take on literary studies can be dated to 1993, when John Guillory's Cultural Capital presented the institution as the dominant, if hidden, determinant of literary canons and hermeneutic practices in the twentieth century. In the midst of the culture wars, Guillory's history offered a salient reminder that making the literary canon 
more "representative" of minority writers was not equivalent to changing the social status of minorities-to think otherwise was to confuse literary representation with political representation and to ignore the school as a site where social status is reproduced.

Almost twenty years after Cultural Capital, it now seems difficult to imagine the scholarly and pedagogical practices of English as connected to anything other than the school, and critics' widespread adoption of Guillory's analysis has had the strange effect of rendering the decisions we make about what to teach and how to teach it, what to research and how to value it, seem moot. In chastening literary critics' tendency to overestimate their classrooms' impact on the world, Guillory's analysis has ended in foreclosing the possibility that our classrooms connect to the world at all, however modestly. Here, we have focused our attention on the weaker ways in which classrooms and histories connect (a method which might well capture the ways that the inclusion of minority writers in the literary canon did have worldly effects, if not ones immediately equivalent to increased political representation). Cultural Capital ends with Guillory's (and, as he points out, Marx's) "thought experiment" in producing an aesthetic experience free from the alienations wrought by capitalism, his wish for a utopian world of universal access to art in which "what we call canon formation would . . . become a much larger part of social life." ${ }^{59}$ We hope that by regrounding disciplinary history in the classroom, we might bring a modest and modified version of Guillory's utopia a little bit closer to reach.

\section{Swarthmore College UNIVERSITY OF NORTH FloridA}

This essay was awarded the 2011 Ralph Cohen Prize. NOTES

\footnotetext{
A postdoctoral fellowship from the Pembroke Center for Research and Teaching on Women at Brown University supported Laura Heffernan during the research stage of this project. 1 Nicholas Dames, The Physiology of the Novel: Reading, Neural Science, and the Form of Victorian Fiction (Oxford: Oxford Univ. Press, 2007), 3.

2 David Kurnick, "An Erotics of Detachment: Middlemarch and Novel-Reading as Critical Practice," ELH 74, no. 3 (2007): 597.

3 Mary Poovey, Genres of the Credit Economy: Mediating Value in Eighteenth- and NineteenthCentury Britain (Chicago: Univ. of Chicago Press, 2008), 319.

4 Elaine Freedgood, The Ideas in Things: Fugitive Meaning in the Victorian Novel (Chicago: Univ. of Chicago Press, 2006), 139-58.

5 John Guillory, "How Scholars Read," ADE Bulletin 146 (Fall 2008): 9-10.

6 Rita Felski, Uses of Literature (Oxford: Blackwell, 2008), 14.
} 
7 Sharon Marcus and Stephen Best, "Surface Reading: An Introduction," in The Way We Read Now, ed. Best and Marcus, Representations 108, no. 1 (2009): 1-21. Franco Moretti, Graphs, Maps, Trees: Abstract Models for a Literary History (London: Verso, 2005).

8 Marjorie Levinson, "What is New Formalism?" PMLA 122, no. 2 (2007): 558-69. James English, "Literary Studies," in The SAGE Handbook of Cultural Analysis, ed. Tony Bennett and John Frow (Los Angeles: SAGE, 2008), 127.

9 Best and Marcus, "Surface Reading," 6.

10 Jane Gallop, "The Historicization of Literary Studies and the Fate of Close Reading," Profession (2007): 181-86.

11 Bruno Latour, "Why Has Critique Run Out of Steam? From Matters of Fact to Matters of Concern," Critical Inquiry 30, no. 2 (2004): 241.

12 Latour, "Why Has Critique Run Out of Steam?" 232.

13 Eve Kosofsky Sedgwick, "Paranoid Reading and Reparative Reading; or, You're so Paranoid, You Probably Think This Essay is About You," in Touching Feeling: Affect, Pedagogy, Performativity (Durham, NC: Duke Univ. Press, 2003), 149.

14 John Kucich questions "the claim that recent criticism has generally sought to master the text by unveiling its truth, essence, or secret" that is a common feature of recent disciplinary histories, a claim that tends to reduce historicism to ideology critique and ideology critique to the "hermeneutics of suspicion." We suggest that such rote forms of suspicious critique are in fact common to disciplinary history rather than to literary historicisms. See Kucich, "The Unfinished Historicist Project: In Praise of Suspicion," Victoriographies 1, no. 1 (2011): 58-78.

15 Edward Said, "Opponents, Audiences, Constituencies and Community," in The AntiAesthetic: Essays on Postmodern Culture, ed. Hal Foster (New York: The New Press, 1998), 159.

16 Cleanth Brooks, "The Language of Paradox," in The Well Wrought Urn: Studies in the Structure of Poetry (New York: Harcourt, Brace, 1947), 5, 18, 21.

17 Richard Strier describes the marriage of interpretive and evaluative practices that lies at the heart of New Criticism in "How Formalism Became a Dirty Word \& Why We Can't Do Without It," in Renaissance Literature and Its Formal Engagements, ed. Mark Rasmussen (New York: Palgrave, 2002), 208-15.

18 Brooks, "The Language of Paradox," 15.

19 These lectures were never published.

20 Yale Course Critique 1963, Cleanth Brooks, YCAL MSS30, Box 81, folder 1657. Beinecke Library, Yale University.

21 Cleanth Brooks, Modern Poetry Lecture \#5 transcript [corrected and retyped]. 13 February 1963. YCAL MSS30, Box 81, folder 1662. Beinecke Library, Yale University, 1-2. 22 Eve Kosofsky Sedgwick, "Shame in the Cybernetic Fold," in Touching Feeling: Affect, Pedagogy, Performativity (Durham, NC: Duke Univ. Press, 2003), 101.

23 Brooks, Lecture \#1, folder 1658 (4 February 1963): 9.

24 Brooks, Lecture \#3, folder 1660 (8 February 1963): 14.

25 Brooks, Lecture \#4, folder 1661 (11 February 1963): 2.

26 Brooks, Lecture \#1, folder 1658 (4 February 1963): 6-8.

27 Brooks, Lecture \#3, folder 1660 (8 February 1963): 19.

28 Brooks, Lecture \#3, folder 1660 (8 February 1963): 7-8.

29 Brooks, Lecture \#1, folder 1658 (4 February 1963): 3-6.

30 Brooks, Lecture \#3, folder 1660 (8 February 1963): 11-12.

31 Brooks, Lecture \#3, folder 1660 (8 February 1963): 4.

32 Even Moore's footnote-free poems are treated, by Brooks, as documents that contain obscure, excessively particular references: "I don't know what that means." "I think this is probably an old-fashioned or whimsical touch." "Since I don't know the Hebrew language, 
this is suggestive, and I am willing to take it on faith. It sounds right, but I don't know." "Is this Thoreau? Could be. Don't remember. Someone of the sort." "Don't ask me what that means. I can think of a dozen things it might mean." Brooks, Lecture \#3, folder 1660 (8 February 1963): 1-17.

33 Brooks, Lecture \#1, folder 1658 (4 February 1963): 10.

34 Brooks, Lecture \#5, folder 1662 (13 February 1963): 14-15.

35 For instance, Brooks says that Rockefeller commissioned Orozco to paint the frescoes, but it was Diego Rivera. When a student explains that the "Mexican artist," intending to satirize Rockefeller, included an image of Lenin, Brooks interrupts: "Yes, Yes, but what happened was that Mr. Rockefeller paid the artist for his work but didn't use the murals in Rockefeller center. And Macleish [sic] decides then that he will provide some frescoes for Mr. Rockefeller's city." Brooks, Lecture \#1, folder 1658 (4 February 1963): 14.

36 Brooks, Lecture \#1, folder 1658 (4 February 1963): 1-3.

37 Brooks, Lecture \#3, folder 1660 (8 February 1963): 1-2.

38 Sianne Ngai, "Merely Interesting," Critical Inquiry 34, no. 4 (2008): 786-87.

39 Robert Martin Adams, "Masks and Delays: Edmund Wilson as Critic," The Sewanee Review 36, no. 2 (1948): 277. See Edmund Wilson, "Is Verse a Dying Technique?" and "Marxism and Literature," both in The Triple Thinkers: Twelve Essays on Literary Subjects (London: J. Lehmann, 1952), 22-36, 188-202.

40 Adams, "Masks and Delays," 277.

41 Charles H. Foster, review of Patriotic Gore: Studies in the Literature of the American Civil War, The New England Quarterly 35, no. 4 (1962): 526.

42 If some academic critics saw Wilson as an historicist who had no account of literary value, other saw-and continue to see-Wilson as a common reader critic for whom questions of value were simple and settled. Both reception histories obscure his very productive career-long struggle with the problem of how to properly interpret and properly value literature within the framework of his historical interests and investment in historicistoften Marxist-methodologies.

43 Indeed, Wilson was widely criticized for failing to provide a strong theory of how historical approaches account for the value of literature in "The Historical Interpretation of Literature" (1940), in which Wilson describes the historicist methodologies of Vico, Taine, Marx, and Engels but attributes their success to their intuitive appreciation of "literature of "Grade A." The Triple Thinkers, 243-55.

44 Edmund Wilson, English 356A: "Varieties of Nineteenth Century Criticism" lecture notes. Summer 1939. YCAL MSS 187, Box 163 folder 4045. Beinecke Library, Yale University.

45 Teaching students to suspend sense in order to "follow the adventures of a letter through any passage that has particularly pleased you," Stevenson's essay must have struck Wilson as especially useful for approaching Finnegans Wake. Robert Louis Stevenson, "On Style in Literature: Its Technical Elements," The Contemporary Review 47 (April 1885): 549. 46 Stevenson, "On Style in Literature: Its Technical Elements," 549.

47 Stevenson, "On Style in Literature: Its Technical Elements," 560.

48 Edmund Wilson papers, handouts for class titled "The Use of Language in Literature," Comparative Literature 290, fall 1959. YCAL MSS 187 Box 163 folders 4055-4056, Beinecke Library, Yale University.

49 Edmund Wilson, lecture notes for English 354: "Charles Dickens" at the University of Chicago, summer 1939. Box 163 folder 4044, YCAL MSS 187 Box 163 folder 4044. Beinecke Library, Yale University.

50 Edmund Wilson, lecture notes for English 175: "The Literature of the American Civil War" at Harvard University, 1959-1960. YCAL MSS 187 Box 163 folder 4053. Beinecke Library, Yale University. 
51 This general revaluing also extended to the fiction and poetry Wilson did include. Puzzled reviewers wanted to know why Wilson apparently "consciously avoid[ed] close engagement" with canonical literature, and included "such irrelevant figures as Poe, Stephen Foster, Frederick Goddard Tuckerman, Thomas Holly Chivers, Ezra Pound, and, of all people Adelaide Crapsey" instead of "Melville, Whitman, and Timrod." Review of Patriotic Gore: Studies in the Literature of the American Civil War, The New England Quarterly, 526.

52 Edmund Wilson, lecture notes for English 175: "The Literature of the American Civil War."

53 Edmund Wilson, lecture notes for English 175: "The Literature of the American Civil War."

54 Edmund Wilson, lectures notes for English 356a: "Varieties of Nineteenth-Century Criticism," 1939. YCAL MSS 187, box 163, folder 4045. Beinecke Library, Yale University. 55 Edmund Wilson, lecture notes for Comparative Literature 290: "The Use of Language in Literature," Harvard University, Fall 1959. YCAL MSS 187 Box 163 folder 4057. Beinecke Library, Yale University.

56 Edmund Wilson, lecture notes for English 30: "An Introduction to James Joyce," 1942. YCAL MSS Box 163 folder 4048. Beinecke Library, Yale University.

57 Edmund Wilson, lecture notes for English 30: "An Introduction to James Joyce."

58 Edmund Wilson, "A Guide to Finnegans Wake," in Classics and Commericals: A Literary Chronicle of the Forties (New York: Farrar, Straus and Giroux, 1950), 188.

59 John Guillory, Cultural Capital: The Problem of Literary Canon Formation (Chicago: Univ. of Chicago Press, 1993), 337, 339. 